\title{
Pengaruh Operating Leverage dan Struktur Modal terhadap Kinerja Keuangan pada Perusahaan Go Publik Sektor Property Dan Real Estate
}

\author{
${ }^{1 *}$ Suhesti Ningsih, ${ }^{2}$ Wikan Budi Utami \\ ${ }^{1,2}$ Tax Management Study Program Sekolah Tinggi Ilmu Ekonomi AAS, Surakarta, Indonesia \\ *Email korenpondensi: hesti.hegi@gmail.com
}

\begin{abstract}
The company's financial performance is a benchmark for the success of managers in running a company. This study aims to determine the effect of operating leverage and capital structure partially or simultaneously on financial performance in the Go Public Company Property and Real Estate Sector. The sampling technique in this study is to use purposive sampling. Data analysis method in this study uses multiple regression analysis which is used to determine the effect of independent variables on the dependent variable together ( $F$ test) and partially ( $t$ test) and $R 2$ test (coefficient of determination) carried out to find out how much influence the operating variable leverage (DOL) and capital structure (DER) on financial performance variables (ROA). From the t test results it is known that the variable operating leverage (DOL) and capital structure variables $(D E R)$ with a significance value of 0.044 and $0.015<0.05$ have a significant effect on financial performance (ROA). F test results prove that operating leverage (DOL) and capital structure (DER) simultaneously have a significant effect on financial performance variables (ROA) in public property and real estate companies listed on the Indonesia Stock Exchange in 2015 -2017.
\end{abstract}

Keyword : capital structure, financial performance. operating leverage.

Saran sitasi: Ningsih, S., \& Utami, W. B. (2020). Pengaruh Operating Leverage dan Struktur Modal terhadap Kinerja Keuangan pada Perusahaan Go Publik Sektor Property Dan Real Estate. Jurnal Akuntansi dan Pajak, 20(2), 154-160. doi: http://dx.doi.org/10.29040/jap.v20i2.754

\section{DOI: $\underline{\text { http://dx.doi.org/10.29040/jap.v20i2.754 }}$}

\section{Pendahuluan}

Kinerja keuangan merupakan bagian penting dalam mencapai tujuan perusahaan. Kinerja keuangan perusahaan merupakan tolok ukur keberhasilan manajer dalam menjalankan perusahaan. Kinerja keuangan merupakan indikator penting yang perlu diperhatikan oleh investor karena menunjukkan pencapaian manajemen dalam menyejahterakan para pemegang saham serta menunjukkan kinerja perusahaan dalam rentang waktu tertentu. Kinerja keuangan mengukur tingkat profitabilitas dan likuiditas sehingga para pemegang saham dapat membandingkan dan mengevaluasi kinerja keuangan masa lampau dengan kinerja perusahaan pada tahun berjalan (Siro, 2013).

Pengukuran kinerja keuangan perusahaan menurut Weston dan Copeland (2007) dilakukan menggunakan rasio profitabilitas. Salah satu rasio profitabilitas untuk mengukur kinerja keuangan adalah Return On Aset (ROA). ROA digunakan untuk mengukur kemampuan perusahaan dalam menghasilkan keuntungan terhadap jumlah aktiva keseluruhan pada suatu perusahaan. Hasil penelitian Ningsih (2017) menemukan bahwa manajemen laba melalui aktivitas-aktivitas riil berpengaruh terhadap kinerja perusahaan.

Menurut Sudana (2011:157), operating leverage timbul bila perusahaan dalam operasinya menggunakan aktiva tetap. Penggunaan aktiva tetap akan menimbulkan beban tetap berupa penyusutan. Perusahaan yang mempunyai operating leverage yang tinggi, maka break event point (BEP) akan tercapai pada tingkat penjualan yang relatif tinggi,dan dampak perubahan tingkat penjualan terhadap laba akan semakin besar jika operating leverage-nya semakin tinggi. Operating leverage digunakan untuk mengukur perubahan pendapatan atau penjualan terhadap keuntungan operasi 


\section{Jurnal Akuntansi dan Pajak, 20(02), 2019, 155}

perusahaan. Besar kecilnya leverage operasi dalam penelitian ini dihitung dengan DOL (Degree of operating leverage).

Struktur modal merupakan faktor yang sangat penting bagi pertumbuhan dan daya tahan perusahaan. Struktur modal secara signifikan berpengaruh terhadap beban dan ketersediaan modal sehingga mempengaruhi kinerja perusahaan. Sementara itu, struktur modal yang kurang optimal mempengaruhi kinerja dan meningkatkan risiko kegagalan bisnis. Struktur modal dalam penelitian ini diukur dengan rasio Debt to total equety Ratio (DER)

Menurut Fahmi (2013) kinerja keuangan adalah suatu analisis yang dilakaukan untuk melihat sejauh mana suatu perusahaan telah melaksanakan aturanaturan pelaksanaan keuangan secara baik dan benar. Dalam mengukur kinerja keuangan perusahaan digunakan ukuran-ukuran kinerja. Ukuran-ukuran kinerja mencerminkan keputusan-keputusan strategis, operasi dan pembiayaan. Informasi dari analisis kinerja keuangan diperlukan untuk menilai perubahan potensial sumber daya ekonomi yang mungkin dikendalikan di masa depan dan untuk memprediksi kapasitas produksi Dari sumber daya yang ada. Kinerja keuangan perusahaan diukur dengan menggunakan Return on Assets (ROA), Return on Equity (ROE), dan Net Profit Margin (NPM). Rasio keuangan yang digunakan untuk mengukur kinerja keuangan perusahaan dalam penelitian ini adalah Return On Asset (ROA). ROA merupakan rasio profitabilitas yang dihitung dari laba bersih setelah pajak terhadap total aktiva (Horne dan Wachowicz 2012:182). Return on Asset digunakan untuk mengukur kemampuan perusahaan secara keseluruhan dalam menghasilkan keuntungan terhadap jumlah aktiva secara keseluruhan yang tersedia pada perusahaan. Semakin tinggi rasio ini maka semakin baik kondisi suatu perusahaan. Rasio ini penting bagi pihak manajemen untuk mengevaluasi efektivitas dan efisiensi manajemen perusahaan dalam mengelola seluruh aktiva perusahaan. ROA dihitung dengan membagi laba setelah bunga dan pajak dengan total aset perusahaan, yang bersumber dari modal pinjaman (liabilitas) dan modal sendiri. Semakin besar nilai ROA menunjukkan semakin besar laba yang dihasilkan dari total aset perusahaan. Dengan demikian, semakin tinggi nilai $R O A$ menunjukkan kinerja keuangan perusahaan yang semakin baik.
Menurut Brigham dan Huston (2011:160), Operating Leverage adalah seberapa besar biaya tetap digunakan dalam operasi suatu perusahaan. Dengan menggunakan operating leverage perusahaan mengharapkan perubahan penjualan akan mengakibatkan perubahan laba sebelum bunga dan pajak yang lebih besar. Operating leverage bekerja secara dua arah, yaitu memperbesar keuntungan perusahaan ataupun memperbesar kerugian perusahaan. Operating leverage timbul sebagai suatu akibat dari adanya beban-beban tetap yang ditanggung dalam operasional perusahaan. Perusahaan yang memiliki biaya operasi tetap atau biaya modal tetap, maka perusahaan tersebut menggunakan leverage. Dengan menggunakan operating leverage perusahaan mengharapkan bahwa perubahan penjualan akan mengakibatkan perubahan laba sebelum bunga dan pajak yang lebih besar. Beban tetap operasional tersebut biasanya berasal Dari biaya depresiasi, biaya produksi dan pemasaran yang bersifat tetap misal gaji karyawan. Sebagai kebalikannya adalah beban variabel operasional. Contoh biaya variabel adalah biaya tenaga kerja yang dibayar berdasarkan produk yang dihasilkan. Operating leverage digunakan untuk mengukur perubahan pendapatan atau penjualan terhadap keuntungan operasi perusahaan. Dilihat Dari kegunaan operating leverage, dapat disimpulkan bahwa perusahaan dapat mengetahui perubahan laba operasi sebagai akibat perubahan penjualan, sehingga perusahaan dapat mengetahui keuntungan operasi perusahaan. Dengan kata lain pengaruh perubahan volume penjualan $(\mathrm{Q})$ terhadap laba sebelum bunga dan pajak (EBIT). Besar kecilnya leverage operasi dihitung dengan DOL (Degree of operating leverage). Analisis leverage operasi dimaksudkan untuk mengetahui seberapa peka laba operasi terhadap perubahan hasil penjualan dan berapa penjualan minimal yang harus diperoleh agar perusahaan tidak mendarita kerugian.

Syamsuddin (2011) menyatakan bahwa, jika suatu perusahaan mengalami operating leverage yang tinggi, maka sedikit saja peningkatan pada penjualan dapat meningkatkan prosentase yang besar pada EBIT. Sebaliknya, jika perusahaan mempunyai operating leverage yang rendah, maka penurunan dalam penjualan akan menyebabkan penurunan jumlah EBIT yang tidak proporsional. Perusahaan yang menggunakan biaya tetap dalam proporsi yang tinggi (relatif terhadap biaya variabel) dikatakan menggunakan operating leverage yang tinggi. 


\section{Jurnal Akuntansi dan Pajak, 20(02), 2019, 156}

Dengan kata lain, degree of operating leverage (DOL) untuk perusahaan tersebut tinggi. Perubahan penjualan yang kecil akan mengakibatkan perubahan pendapatan yang tinggi (lebih sensitive). Jika perusahaan mempunyai degree of operating leverage ( $D O L$ ) yang tinggi, tingkat penjualan yang tinggi akan menghasilkan pendapatan yang tinggi.

Menurut Abdul Hakim (2015:45) struktur modal adalah gambaran dari bentuk proporsi finnsial perusahaanyaitu antara modal yang dimiliki yang bersumber dari hutang jangka panjanag dan modal sendiri yang menjadi sumber pembiayaan suatu perusahaan. Permasalahan yang dihadapi perusahaan adalah bagaimana suatu perusahaan tersebut dengan cepat dapat memadukan dana permanen yang digunakannya dengan mencari panduan dana yang dapat meminimumkan modal perusahaan dan dapat memaksimalkan harga saham. Struktur modal menjadi masalah yang sangat penting bagi suatu perusahaan karena baik buruknya struktur modal akan mempengaruhi kondisi keuangan perusahaan yang pada akhirnya juga akan mempengaruhi nilai perusahaan. Beberapa teori yang mendasari struktur modal diantaranya Modigliani-Miller (MM) theory, pecking order theory, trade- off theory (teori pertukaran), signaling theory.

Modigliani-Miller (MM) theory menyatakan bahwa tidak ada rasio hutang yang optimal dan rasio hutang tidak menjelaskan nilai perusahaan dan teori ini menggunakan asumsi bahwa tidak ada pajak, tidak ada asimetri informasi dan tidak ada biaya transaksi akan tetapi teori ini dikatakan kurang relevan karena adanya pengurangan pajak penghasilan atas penggunaan hutang, kondisi pasar dengan asimetri informasi serta biaya transaksi dalam pasar modal yang tidak dimasukkan ke dalam teori MM (Brigham dan Houston, 2011:179)

Pecking order theory menyatakan bahwa : (1) perusahaan menyukai internal financing (pendanaan Dari hasil operasi perusahaan), (2) perusahaan mencoba menyesuaikan rasio pembagian dividen yang ditargetkan, dengan berusaha menghinDari perubahan pembayaran dividen secara drastis, (3) kebijakan dividen yang relatif cenderung kaku, disertai dengan fluktuasi profitabilitas dan kesempatan investasi yang tidak bisa diduga, mengakibatkan bahwa dana hasil operasi kadangkadang melebihi kebutuhan dana untuk investasi, meskipun pada kesempatan yang lain, mungkin kurang, (4) apabila pendanaan Dari luar (external financing) diperlukan, maka perusahaan akan menerbitkan sekuritas yang paling "aman" terlebih dulu dimulai dengan penerbitan obligasi, kemudian diikuti oleh sekuritas yang berkarakteristik opsi (seperti obligasi konversi), baru akhirnya apabila masih belum mencukupi, saham baru diterbitkan (Husnan, 2012:325).

Beberapa penelitian mengenai analisis pengaruh operating leverage(DOL), struktur modal(DER) terhadap kinerja keuangan perusahaan (ROA) telah banyak dilakukan. Setiawan dkk (2019) meneliti tentang pengaruh Degree Operating Leverage (DOL), Degree Financial Leverage (DFL) terhadap profitabilitas pada PT Waskita Karya Persero Tbk., dengan hasil bahwa baik secara parsial maupun secara simultan menunjukkan degree of operating leverage (DOL) dan degree financial leverage $(D F L)$ tidak berpengaruh terhadap profitabilitas.

Kristianti (2018) melakukan penelitian dengan judul Analisis Pengaruh Struktur Modal Terhadap Kinerja Keuangan Perusahaan dengan hasil bahwa struktur modal memiliki pengaruh signifikan dan positif terhadap kinerja keuangan perusahaan.

Tambunan dan Prabawani (2018) yang meneliti tentang Pengaruh Ukuran Perusahaan, Leverage dan Struktur Modal Terhadap Kinerja Keuangan Perusahaan menyimpulkaan bahwa leverage berpengaruh terhadap kinerja keuangan perusahaan sedangkan ukuran perusahaan dan struktur modal tidak berpengaruh terhadap kinerja keuangan perusahaan, dan secara simultan menunjukkan bahwa ukuran perusahaan, leverage dan struktur modal secara simultan terhadap kinerja keuangan perusahaan.

Penelitian Ifada dan Inayah menggunakan dua variabel dalam menganalisis tingkat leverage yaitu Debt Ratio (DR) dan Debt to Equity Ratio (DER), serta penggunaan Return on Equity (ROE) untuk menganalisis kinerja perusahaan, hasil penelitian menunjukkan bahwa leverage berpengaruh terhadap kinerja perusahaan sehingga perusahaan harus lebih memperhatikan tingkat hutang.

Nopitasari dkk (2015) meneliti tentang pengaruh leverage terhadap kinerja perusahaan pada perusahaan sektor property dan real estate yang teredaftar di Bursa Efek Indonesia membuktikan bahwa financial leverage berpengaruh positif dan signifikan terhadap kinerja keuangan perusahaan property dan real estate. 


\section{Jurnal Akuntansi dan Pajak, 20(02), 2019, 157}

Hasil temuan yang berbeda dari para peneliti peneliti yang telah diuraikan di atas, maka penulis tertarik untuk menguji kembali pengaruh operating leverage dan struktur modal terhadap kinerja perusahaan pada perusahaan go publik sektor property dan real estate yang terdaftar di Bursa Efek Indonesia tahun 2015-2017.

Berdasarkan uraian diatas maka dapat dibuat hipotesa sebagai berikut:

H1: Terdapat pengaruh operating leverage secara parsial tehadap kinerja perusahaan.

H2: Terdapat pengaruh struktur modal secara parsial terhadap kinerja perusahaan

H3: Terdapat pengaruh operating leverage dan struktur modal secara simultan terhadap kinerja perusahaan.

\section{Metodologi Penelitian}

\subsection{Metode, sampel dan populasi}

Meode Penelitian yang digunakan adalah metode kuantitatif. Sampel dalam penelitian ini adalah Perusahaan property and real estate yang terdaftar di Bursa Efek Indonesia tahun 2015 sampai dengan 2017. Teknik pengambilan sampel dalam penelitian ini adalah teknik purposive sampling yaitu data yang dipilih berdasarkan kriteria-kriteria tertentu yang sesuai dengan tujuan penelitian dengan kriteria sebagai berikut:

a. Perusahaan property and real estate yang sudah dan masih terdaftar di Bursa Efek Indonesia pada tahun 2015 sampai dengan 2017

b. Perusahaan yang menerbitkan laporan keuangan selama periode tersebut

c. Perusahaan yang mencatat laporan keuangan secara lengkap.

\subsection{Tehnik Pengumpulan}

Teknik pengumpulan data dalam penelitian ini adalah dokumentasi. Dokumentasi menurut Sugiyono (2015: 329) adalah suatu cara yang digunakan untuk memperoleh data dan informasi dalam bentuk buku, arsip, dokumen, tulisan angka dan gambar yang berupa laporan serta keterangan yang dapat mendukung penelitian. Dokumentasi digunakan untuk mengumpulkan data kemudian ditelaah. Data-data yang diambil berasal dari jurnal dan laporan keuangan perusahaan yang telah terdaftar di Bursa Efek Indonesia (BEI).

\subsection{Definisi Operasional Variabel}

Variabel dependen dalam penelitian ini adalah kinerja perusahaan. Menganalisis kinerja keuangan dilakukan dengan menganalisis laporan keuangan.
Dalam kegiatan operasional perusahaan, laba merupakan elemen yang penting dalam kelangsungan perusahaan. Kemampuan perusahaan dalam menghasilkan keuntungan selama periode tertentu melalui kegiatan operasionalnya disebut profitabilitas (Brigham \& Houston, 2014).

Rasio profitabilitas adalah rasio yang mengukur tingkat efektifitas manajemen berdasarkan hasil pengembalian yang dihasilkan dari penjualan dan investasi. Rasio dari profitabilitas yang digunakan dalam penelitian ini yaitu menggunakan Return on Investment (ROA) sebagai ukuran profitabilitas. Brigham dan Houston (2011:189) mengatakan bahwa perusahaan dengan tingkat pengembalian yang tinggi atas investasi menggunakan hutang yang kecil. Return on investmen (ROA) dapat dihitung dengan rumus:

$$
R O A=\frac{\text { Laba bersih setelah pajak }}{\text { Total asset }}
$$

Variabel Independen dalam penelitian ini adalah:

\section{a. Operating Leverage $\left(\mathrm{X}_{1}\right)$}

Warsono (2003) Operating Leverage dapat operasi untuk memperbesar pengaruh perubahan dalam penjualan terhadap laba sebelum bunga dan pajak perusahaan. Operating leverage dapat diukur menggunakan Degree of Operating leverage (DOL). Degree of Operating Leverage dapat dihitung menggunakan rumus berikut:

$$
D O L=\frac{\text { Prosentase perubahan EBIT }}{\text { Prosentase perubahan penjualan }}
$$

b. Ukuran Perusahaan $\left(\mathrm{X}_{2}\right)$

Ferri dan Jones ( dalam Elyana, 2007) menyatakan bahwa ukuran perusahaan menggambarkan besar kecilnya suatu perusahaan yang ditunjukkan oleh total aktiva, jumlah penjualan dan rata-rata aktiva. Skala perusahaan merupakan ukuran yang dipakai untuk mencerminkan besar kecilnya perusahaan yang didasarkan kepada total aset perusahaan (Suwito dan Herawaty, 2005). Menurut Saidi (2005) ukuran perusahaan dalam penelitian ini diukur menggunakan Natural Log total aktiva. Untuk rumus yang digunakan sebagai berikut:

Size $=$ Natural Log Total Aset

Total Aset $=$ Aset Lancar + Aset Tidak Lancar

c. Struktur Modal

Struktur modal adalah perimbangan pemakaian hutang jangka panjang untuk membiayai investasinya, sehingga dapat diketahui keseimbangan antara tingkat risiko dan tingkat 


\section{Jurnal Akuntansi dan Pajak, 20(02), 2019, 158}

pengembalian investasinya (Nurrohim, 2008). Dalam struktur modal menggunakan pengukuran Debt to asset ratio (DER). Rasio DER untuk mengukur kemampuan perusahaan dalam memenuhi kewajiban dalam membayar hutangnya dengan jaminan modal sendiri. Untuk menghitung debt to asset ratio(DER) sebagai berikut:

\subsection{Metode Analisi Data}

$$
\text { DER }=\frac{\text { Total Debt }}{\text { Total Ratio }}
$$

Metode analisis data yang digunakan dalam penelitian adalah analisis regresi berganda dengan bantuan komputer melalui program SPSS 21.0 for Windows. Uji regresi linier berganda digunakan untuk mengetahui pengaruh variabel independen terhadap variabel dependen pada hipotesis yang telah dibuat. Persamaan regresi yang digunakan adalah sebagai berikut (Ghozali, 016)

Dimana:

$$
\mathrm{Y}=\alpha+\beta 1 \mathrm{X} 1+\beta 2 \mathrm{X} 2+e
$$

$$
\begin{array}{ll}
\alpha & =\text { Konstanta } \\
\mathrm{Y} & =\text { Variabel Dependen } \\
\beta 1 \beta 2 \beta 3 & =\text { Nilai Koefisien Regresi } \\
\mathrm{X} 1 & =\text { Variabel Independen ke-1 } \\
\mathrm{X} 2 & =\text { Variabel Independen ke-2 }
\end{array}
$$

Selanjutnya dilakukan uji hipotesis menggunakan Uji t(uji parsial) dan Uji $F$ (uji simultan). Uji t digunakan untuk mengetahui apakah variable bebas secara parsial berpengaruh terhadap variable terikat. Uji $\mathrm{F}$ digunakan untuk mengetahui apakah variabel bebas secara simultan berpengaruh terhadap variabel terikat. Derajat signifikan yang digunakan adalah 0,05 (5\%). Koefisien determinasi $\left(\mathrm{R}^{2}\right)$ digunakan untuk mengetahui seberapa jauh

\begin{tabular}{|c|c|c|c|c|}
\hline Variabel & $\mathrm{b}$ & $t_{\text {hitung }}$ & Sig & Kesimpulan \\
\hline Konstans & 0,109 & & & \\
\hline DOL & 0,002 & 2,016 & 0,044 & $\begin{array}{c}\text { Berpengaruh } \\
\text { Signifikan }\end{array}$ \\
\hline DER & $-0,052$ & $-2,499$ & 0,015 & $\begin{array}{c}\text { Berpengaruh } \\
\text { Signifikan }\end{array}$ \\
\hline \multicolumn{2}{|c|}{$F_{\text {hitung }}$} & 3,849 & 0,025 & $\begin{array}{c}\text { Berpengaruh } \\
\text { Signifikan }\end{array}$ \\
\hline \multicolumn{2}{|c|}{$\mathrm{R}^{2}$} & \multicolumn{3}{|c|}{0,066} \\
\hline
\end{tabular}
kemampuan model dalam menerangkan variasi variabel dependen.

\section{Hasil dan Pembahasan}

\subsection{Hasil Penelitian}

Tabel 1.

Rangkuman Hasil Uji Hipotesis

Sumber : Data yg diolah dengan SPSS 21

\section{Uji Regresi Linier Berganda}

Berdasarkan hasil perhitungan SPSS yang nampak di tabel 1 di atas persamaan regresi sebagai berikut:

$$
\mathrm{Y}=0,109+0,002 \mathrm{DOL}-0,052 \mathrm{DER}+\mathrm{e}
$$

Dari hasil analisis dapat diketahui bahwa variabel bebas DOL berpengaruh positif terhadap kinerja keuangan perusahaan (ROA) dengan koefisien sebesar 0,002 . Hal ini berarti apabila DOL meningkat kinerja keuangan (ROA) meningkat pula. Sedangkan variabel bebas DER berpengaruh negatif dengan koefisien -0,052. Hal ini berarti bila DER meningkat maka kinerja keuangan (ROA) menurun dan sebaliknya.

\section{Uji Signifikan Parameter Individual (Uji -t Statistik)}

Uji $t$ digunakan untuk mengetahui signifikansi secara parsial dari variabel independent yaitu: Degree Of Operating Laverage (DOL) dan Debt Equity Ratio (DER) terhadap variabel dependent yaitu: kinerja keuangan perusahaan (ROA).

Dari table 1 di atas diketahui besarnya pengaruh masing-masing variabel independen terhadap variabel dependen adalah sebagai berikut:

1) Uji hipotesis pengaruh Degree Of Operating Laverage (DOL) terhadap kinerja keuangan perusahaan (ROA).

Dari hasil perhitungan signifikasi t untuk variabel Degree Of Operating Laverage (DOL) sebesar $0.044<\alpha(0,05)$ dan $\mathrm{t}_{\text {hitung }}(2.016)>\mathrm{t}$ tabel $(1,991)$.Hal ini berarti berarti Degree Of Financial Laverage (DOL) secara parsiil berpengaruh signifikan terhadap kinerja keuangan (ROA) perusahaan.

2) Uji hipotesis pengaruh Debt Equity Ratio (DER) terhadap kinerja keuangan (ROA) perusahaan.

Dari hasil perhitungan yang diperoleh signifikasi t untuk variabel Debt Equity Ratio (DER) sebesar $0,015<\alpha(0,05)$ dan $\mathrm{t}_{\text {hitung }}\left(2.499>\mathrm{t}_{\text {tabel }}\right.$ 1,991). Hal ini berarti Debt Equity Ratio (DER) berpengaruh signifikan terhadap kinerja keuangan (ROA) perusahaan.

\section{Uji F}

Hasil uji $\mathrm{F}$ dengan program SPSS 21, diketahui besarnya nilai $\mathrm{F}$ hitung $(3,849)>\mathrm{F}$ tabel $(3,11)$ dengan signifikansi $0,025<\alpha=0,05$, artinya variabel Degree Of Operating Laverage (DOL) dan Debt Equity Ratio (DER) secara simultan berpengaruh signifikan terhadap kinerja keuangan (ROA) perusahaan go publik sektor otomotif dan komponen tahun 2015-2017. 


\section{Koefisien Determinasi (R2)}

Hasil dari perhitungan dengan menggunakan progran SPSS 21 yang nampak pada tabel 1 di atas bahwa koefisien determinasi $\left(\mathrm{R}^{2}\right)$ yang dapat dilihat dari nilai adjusted $R$ Square sebesar 0,46 . Hal ini berarti $46 \%$ kinerja keuangan (ROA) perusahaan dapat dijelaskan oleh variabel Degree Of Operating Laverage (DOL) dan Debt Equity Ratio (DER) sedangkan sisanya sebesar $54 \%$ dipengaruhi oleh variabel lain yang tidak diteliti dalam penelitian ini.

\subsection{Pembahasan}

Dari hasil pengujian hipotesis pertama, menunjukkan bahwa operating leverage (DOL) berpengaruh signifikan terhadap kinerja perusahaan (ROA). Hal ini bisa dilihat dari hasil uji $\mathrm{t}$ dengan nilai signifikansi $0,044<0,05$ dan $\mathrm{t}_{\text {hitung }}(2.016>$ $\left.t_{\text {tabel }} 1,991\right)$.

Brigham dan Huston (2011:160) mendefinisikan Operating Leverage adalah seberapa besar biaya tetap digunakan dalam operasi suatu perusahaan. Operating leverage bekerja secara dua arah, yaitu memperbesar keuntungan perusahaan ataupun memperbesar kerugian perusahaan. Operating leverage timbul sebagai suatu akibat dari adanya beban-beban tetap yang ditanggung dalam operasional perusahaan. jika suatu perusahaan mengalami operating leverage yang tinggi, maka sedikit saja peningkatan pada penjualan dapat meningkatkan prosentase yang besar pada EBIT (Syamsudin:2011).

Adanya pengaruh operating leverage terhadap kinerja perusahaan hal ini menunjukkan bahwa perusahaan harus dapat memaksimalkan penjualan dan meminimalkan beban-beban operasional sehingga perusahaan peka terhadap perubahan hasil penjualan dan berapa penjualan minimal yang harus diperoleh agar perusahaan tidak menderita kerugian. Adanya operasional leverage yang baik maka dapat menghasilkan profitabilitas sehingga terjadinya kinerja keuangan perusahaan yang baik.

Hasil penelitian ini sejalan hasil penelitian dari Tambunan dan Brawani, (2018); Nopitasari dkk (2015) yang membuktikan bahwa leverage berpengaruh terhadap kinerja keuangan perusahaan

Bertolak belakang dengan hasil penelitian dari Setiawan dkk (2019) meneliti tentang pengaruh Degree Operating Leverage (DOL), Degree Financial Leverage (DFL) terhadap profitabilitas pada PT Waskita Karya Persero Tbk., membuktikan bahwa baik secara parsial maupun secara simultan degree of operating leverage (DOL) dan degree
Pajak, 20(02), 2019, 159

financial leverage (DFL) tidak berpengaruh terhadap profitabilitas.

Uji hipotesis yang kedua membuktikan bahwa struktur modal yang diukur dengan debt to equity ratio (DER) berpengaruh signifikan terhadap kinerja keuangan (ROA) perusahaan, yang ditunjukkan dengan nilai signifikansi $\mathrm{t}(0,015)<\alpha=0,05$ dan nilai $\mathrm{t}_{\text {hitung }}(12,499)>\mathrm{t}_{\text {tabel }}(1,991)$.

Debt to Equity Ratio (DER) merupakan rasio yang memperlihatkan sejauh mana ekuitas perusahaan dapat menjamin hutang kepada pihak luar dan mengukur sejauh mana aktivitas perusahaan di biayai dengan hutang. Debt to Equity Ratio merupakan pemanfaatan hutang untuk pendanaan usaha atau sebagai sumber modal yang digunakan perusahaan untuk menambah modal dalam operasional perusahaan.

DER berpengaruh positif terhadap kinerja keuangan, artinya semakin tingginya nilai debt to equity ratio, maka berarti kinerja keuangan yang ada di perusahaan juga akan semakin meningkat. Hal ini mengindikasikan bahwa $D E R$ yang semakin tinggi dapat menggambarkan bahwa perusahaan dapat beroperasi dengan hutang sebagai ekuitasnya. Hutang usaha ini jika di pergunakan secara tepat dapat menghasilkan profit yang meningkat bila di bandingkan dengan oeprasional dengan menggunakan ekuitasnya sendiri. Karena dengan bertambahnya hutang, maka akan menambah dana (ekuitas) perusahaan yang akan di pergunakan untuk peningkatan aktivitas laba perusahaan. DER mempunyai pengaruh positif terhadap kinerja perusahaan karena perusahaan lebih banyak menggunakan hutang untuk pendanaan usaha sebagai sumber tambahan modal usaha.

Hasil penelitian ini mendukung hasil dari penelitian Dwi (2014) yang menyatakan bahwa $D E R$ berpengaruh positif terhadap kinerja keuangan. Penggunaan hutang mempengaruhi kinerja perusahaan, sehingga perusahaan harus memperhatikan tingkat leverage (Ifada dan Inayah (2017). Hasil dari penelitian ini juga sejalan dengan penelitian yang sudah dilakukan oleh Kristianti (2018), Antonie (2018) bahwa struktur modal memiliki pengaruh signifikan dan positif terhadap kinerja keuangan perusahaan. Saran perusahaan harus memperhatikan perbandingan jumlah hutang dengan modal sendiri agar struktur modal yang optimal dapat tercapai kinerja keuangan meningkat.

Berbeda dengan hasil penelitian dari Tambunan dan Brawani, (2018) yang meneliti tentang Pengaruh 


\section{Jurnal Akuntansi dan Pajak, 20(02), 2019, 160}

Ukuran Perusahaan, Leverage dan Struktur Modal Terhadap Kinerja Keuangan Perusahaan membuktikan bahwa ukuran perusahaan dan struktur modal tidak berpengaruh terhadap kinerja keuangan perusahaan.

Nilai koefisien determinasi $\left(\mathrm{R}^{2}\right)$ yang dapat dilihat dari nilai adjusted $R$ Square sebesar 0,46. Hal ini berarti $46 \%$ kinerja keuangan (ROA) perusahaan dapat dijelaskan oleh variabel Degree Of Operating Laverage (DOL) dan Debt Equity Ratio (DER) sedangkan sisanya sebesar $54 \%$ dipengaruhi oleh variabel lain yang tidak diteliti dalam penelitian ini.

\section{Kesimpulan}

Dari hasil uji t membuktikan bahwa operating leverage (DOL) berpengaruh signifikan terhadap kinerja keuangan (ROA) perusahaan dengan nilai signifikan t $0,044<\alpha=0,05$. Hasil uji t pada variable struktur modal yang diukur menggunakan debt to equity ratio (DER) mempunyai nilai signifikansi t sebesar $0,015<\alpha=0,05$ maka hal ini menunjukkan bahwa $D E R$ berpengaruh signifikan terhadap kinerja keuangan (ROA) perusahaan.

Secara simultan yaitu dari hasil uji $\mathrm{F}$ diperoleh nilai signifikansi $F$ sebesar $0,025<\alpha=0,05$ yang berarti bahwa variabel operating leverage $(D O L)$ dan struktur modal (DER) secara bersama-sama berpengaruh terhadap kinerja keuangan (ROA) perusahaan. Dilihat dari nilai adjusted $\mathrm{R}^{2}$ sebesar 0,46 yang berarti variabel operating leverage dan struktur modal mempengaruhi nilai perusahaan sebesar $46 \%$ sisanya sebesar $54 \%$ dipengaruhi oleh variabel-variabel lain diluar penelitian.

\section{Daftar Pustaka}

Brigham, E.F. dan J.F. Houston. (2011). DasarDasar Manajemen Keuangan. Buku 2 Edisi 16. Jakarta : Salemba Empat.

Fahmi, I. (2013). Analisis Laporan Keuangan, Cetakan ketiga. Bandung: Alfabet

Ghozali, Imam. 2016. Aplikasi Analisis Multivariate dengan Program SPSS. Semarang : Badan Penerbit Universitas Diponegoro.

Halim, Abdul (2015). Manajemen Keuangan Bisnis, Konsep dan Aplikasinya. Jakarta Mitra Wacana. Buku 1 Edisi Global Asia Jakarta

Horne, James C. Van dan Wachowichz, Jr. (2012). Prinsip-Prinsip Manajemen Keuangan. Edisi 13. Salemba Empat. Jakarta.

Husnan, Suad. (2012). Manajemen Keuangan Teori dan Penerapan, Buku 2, Yogyakarta:BPFE.
Ifada, luluk M \& Inayah, Nayirotul (2017). Analisis

Pengaruh Tingkat Leverage Terhadap Kinerja Perusahaan, Fokus Ekonomi Vol. 12 No.1 Juni $2017: 19-36$

Kristianti, Ika Puspita (2018), Analisis Pengaruh Struktur Modal Terhadap Kinerja Keuangan Perusahaan, Jurnal Akuntansi Dewantara, Univ. Sarjana Wiyata, vol 2 no. 2 tahun 2018 hal 56-68

Ningsih, Suhesti (2017), The Effect of Real Earning Management on Company Performance (Empirical Study on Go Public Companies Indexed on JII), International Journal Of Economic, Bussined and Accounting Research (IJEBAR), STIE AAS, Vol 1 issu 2 tahun 2017 hal 34-46, ISSN: 2614-1280

Nopitasari, Hana, Tiorida, Ermina \& Sara, Ira Siti (2017). Analisis Pengaruh Tingkat Leverage Terhadap Kinerja Perusahaan (Studi Pada Perusahaan Properti Dan Real Estate Yang Terdaftar Di Bursa Efek Indonesia Periode 2011-2015), Jurnal Riset Bisnis \& Investasi Vol. 3, No. 3, Desember 201745 ISSN 24608211

Setiawan, Egi, Iskandar, Yusuf dan Basari, M. Aziz (2019). Degree Operating Leverage (DOL), Degree Financial Leverage (DFL) terhadap profitabilitas pada PT Waskita Karya Persero Tbk. Busness Management And Entrepreneurship Journal, Unigal.Vol. 1 No. 2 tahun 2019 Hal. 149-157

Siro, Robert Oginda. 2013. Effect of Capital Strucuture on Financial Performance of Firms Listed at The Nairobi Securities Exchange. Thesis. University of Nairobi.

Sudana, I Made (2011). Manajemen Keuangan Perusahaan Teori dan Praktik. Jakarta: Erlangga

Syamsuddin, L. (2011). Manajemen Keungan Perusahaan. Jakarta : PT Rajagrafindo Persada.

Tambunan, J.T.A \& Prabawani, Bulan (2018). Pengaruh Ukuran Perusahaan, Leverage dan Struktur Modal Terhadap Kinerja Keuangan Perusahaan (Studi Pada Perusahaan Manufaktur Sektor Aneka Industri Tahun 2012-2016) Diponegoro Journal Of Social And Politic Tahun 2018, hal. 1-10.

Weston, J.Fred dan Copeland, Thomas E. (2007).

Manajemen Keuangan jilid 1 dan 2 . Jakarta : Binarupa Askara.

www.idx.co.id 